\title{
ANALISA KIMIA DAN FISIK NANAS KALENG PINEAPLE SOLID PACK PT. RIAU SAKTI UNITED PLANTATIONS - INDUSTRY PULAU BURUNG KABUPATEN INDRAGIRI HILIR PROPINSI RIAU
}

\author{
Bustami*) $^{*}$, dan Susi Salhan, SP., MP ${ }^{* *}$ \\ *) Mahasiswa Faperta UNISI \\ **) Dosen Faperta UNISI
}

\begin{abstract}
Abstrak
PT. RSUP-Industry adalah perusahaan yang bergerak di bidang industri pertanian salah satu produknya adalah nanas kaleng. Untuk menghasilkan mutu dari nanas kaleng perlu dilakukan analisa fisik, kimia dan organoleptik. Analisa Fisik yaitu Net Weight 3062, Drained Weight 1700, Penetuan Jumlah (count), Crush, Head Space, Defect, Dimensi Potongan Nanas. Analisa Kimia yaitu Brix Water 5,0 - 9-9 ${ }^{\circ} \mathrm{B}$, Juice 10,0 - 13,9 ${ }^{\circ} \mathrm{B}$, Light Syrup $14,0-17,9^{\circ} \mathrm{B}$, Heavy Syrup 18,0 - 21,9 ${ }^{\circ} \mathrm{B}$, pH 3,0 - 4,0 , Acidity $30-40 \%$. Analisa Organoleptik yaitu : Uji rasa, aroma, warna, dimana rasa dan aroma harus sesuai dengan rasa dari aroma khas nanas, untuk warna disesuaikan dengan permintaan buyer.
\end{abstract}

\section{PENDAHULUAN}

Nanas (Ananas comosus) sebenarnya bukan tanaman asli Indonesia. Tanaman ini diperkirakan masuk ke Indonesia Tahun 1599, dibawa oleh para pelaut Spanyol dan Portugis. Sejarah juga menyebutkan bahwa Pulau Jawa merupakan tempat yang penduduknya pertama kali mengembangkan tanaman nanas (Haryanto, E dan Hendarto, B 1996)

Sebagai salah satu tanaman hortikultura, nanas sangat cocok dibudidayakan di daerah tropis yang cukup banyak turun hujan. Tanaman ini tidak akan tumbuh baik di tempat yang terlalu kering maupun pada lahan yang airnya tergenang. Di Indonesia, hampir semua daerah dapat dibudidayakan nanas (Haryanto, E dan Hendarto, B 1996)
Hasil utama tanaman nanas adalah buahnya, buah segar yang sudah masak disamping bisa langsung dikonsumsi dapat juga digunakan untuk bahan pembuatan sari buah, sirup, manisan, jus, serta di kemas dalam kaleng sebagai buah dalam kaleng. Komoditas nanas bagi indonesia dapat memberikan peluang luas dalam pengembangan agribisnis, sebab ditinjau dari prospek pemasarannya, dewasa ini permintaan pasar dunia akan komoditas nanas terus meningkat (Rukmana, R. 1996).

Buah yang sering digunakan dalam pembuatan nanas kaleng adalah buah yang berasal dari varietas spanish queen yang memiliki dua tipe. Ciri - ciri tipe 1 yaitu buah berukuran cukup besar, berbentuk silinder, kulit buah yang matang berwarna hijau kekuningan, daging buah berwarna kuning mas, dan halus tidak berduri, kandungan vitamin C sekitar 0,41 mg/1 ml, dan Ciri - ciri 
tipe 2 buah berbentuk bulat telur, kulit buah berbentuk kuning hingga merah, daging buah berwarna putih, dan berduri tajam, kandungan vitamin $\mathrm{C}$ sekitar 0,29 $\mathrm{mg} / 1 \mathrm{ml}$ sari buah segar. (Rukmana,1996)

\section{PT. RSUP-Ind Pulau Burung} salah satu perusahaan yang memproduksi pengolahan nanas kaleng dengan produk yang ditujukan untuk ekspor ke Korea, Jepang, Thailand, Amerika Serikat, Eropa, Fhilipina dan sebagainya. PT. RSUP-Ind Pulau Burung dalam proses pengolahan nanas menghasilkan produk-produk Nanas Kaleng, Juice Cosentrate Nanas. Untuk memperoleh mutu nanas kaleng yang baik perlu dilakukan analisa fisik maupun kimia faktor organoleftiknya sehingga produk yang dihasilkan sesuai dengan standar mutu yang di inginkan.

\section{HASIL DAN PEMBAHASAN}

\section{Laboratorium Pengujian}

Laboratorium adalah salah satu divisi di pabrik nanas kaleng yang berfungsi untuk menganalisa dan penilaian secara keseluruhan dari hasil proses yang berlangsung, ditujukan untuk manajemen hasil yang diinginkan berkaitan dengan efisiensi pabrik dan kualitas akhir produksi.

Dimana laboratorium itu sendiri di lengkapi dengan peralatan-peralatan yang mendukung untuk analisa berdasarkan ketentuan yang sudah ditetapkan.

Tujuan Laboratorium adalah untuk menghasilkan produk yang berkualitas baik dengan tingkat efisiensi ekstraksi yang maksimum dan biaya yang minimum. Ini juga merupakan salah satu tujuan dari laboratorium untuk mendukung hal yang menjadi tujuan dari pabrik itu sendiri.

Secara garis besar fungsi laboratorium adalah sebagai berikut :

1. Memeriksa dan menganalisa kualitas yang diproduksi setiap hari dan apabila terdapat penyimpangan harus diberitahukan kepada manager Quality Assurance Nanas (QAN) dengan segera agar dapat diambil tindakan-tindakan koreksi.

2. Menganalisa kehilangan bentuk selama proses secara teratur dan efisiensi dari proses pengolahan.

3. Menganalisa yang dilakukan sesuai dengan spesifikasi atau permintaan konsumen atau buyer.

Laboratorium pengujian PT. RSUP-Ind Kecamatan Pulau Burung Kabupaten Indragiri Hilir Propinsi Riau memegang peranan yang sangat penting karena di laboratorium pengujian dapat pemeriksaan dan menganalisa produk yang dilakukan dari hasil produksi dan pemeriksaan atau analisa standar mutu yang ditetapkan oleh perusahan tersebut.

Prinsip Good Laboratorium Practice (GLP) atau aturan - aturan, prosedur - prosedur dan praktek laboratorium PT. RSUP-Ind Kabupaten Indragiri Hilir Propinsi Riau sudah ada dan terealisasi secara baik.

\section{Persiapan Contoh Sampel Nanas Kaleng}

Contoh sampel yang digunakan untuk analisa mutu harus dipersiapkan sedemikian rupa sebab contoh memang peranan yang sangat penting didalam melakukan analisa. Contoh yang diambil dari produksi harus mewakili seluruh produk sehingga tujuan dari analisa mutu (Quality Analisa) sesuai dengan tujuan pengujian. Adapun aturan pengambilan sampel adalah sebagai berikut : 
1. Alat-alat yang digunakan untuk pengambilan sampel harus selalu dijaga agar tetap bersih.

2. Sampel harus diberi nama atau identitas

\section{Analisa Fisik}

1. Analisis Net Weight Sampel Nanas Kaleng

Tujuan : Untuk mengetahui berat bersih dari produk.

Prinsip kerja adalah Penimbangan sampel produk utuh dan kaleng standar kosong, selisih berat sampel produk dengan kaleng standar kosong merupakan net weight sampel produk.

Bahan dan Peralatan :

1. Sampel PSP

2. Timbangan (Top Loading Balance)

3. Kaleng kosong yang telah ditutup sebagai kaleng standard

Cara Kerja :

1. Siapkan sampel nanas kaleng

2. Siapkan timbangan

3. Pastikan angka pada timbangan tanpa beban adalah " 0.0 "

4. Penentuan Net Weight adalah sebagai berikut :

a. Letakan kaleng standard dan tutup standard, ukuran kaleng disesuaikan dengan ukuran kaleng sampel. Contoh, jika sampel nanas kaleng berukuran A 10, maka kaleng kosong dan tutupnya yang akan ditimbang adalah ukuran A 10. pastikan kaleng kosong dalam keadaan kering.

b. Tara timbangan ke 0.0

c. Kemudian angkat dan pindahkan kaleng kosong dari atas timbangan tanpa mengganggu timbangan

d. Letakkan sampel nanas kaleng ke atas timbangan, kemudian baca angka yang ditunjukkan

e. Catat hasilnya sebagai net weight yaitu 3062 gram.

2. Analisa Drained Weight Sampel Nanas Kaleng

Tujuan : Analisa Drained Weight adalah untuk mengetahui berat nanas.

Prinsip adalah isi sampel ditiriskan selama 2 menit, berat nanas setelah ditiriskan tersebut merupakan drained weight.

Bahan dan Peralatan :

1. Sampel PSP

2. Timbangan

3. Timer

4. Saringan (sieve) sesuai dengan ukuran kaleng

Cara Kerja :

1. Siapkan sampel nanas kaleng

2. Cara penentuan Drained Weight adalah sebagai berikut:

a. Siapkan pembuka kaleng

b. Siapkan baskom (baskom A), letakkan saringan di atasnya

c. Siapkan timer dan setting alarm untuk jangka 2 menit atau 120 detik

d. Siapkan timbangan dan pastikan angka 0.0 pada display sebelum digunakan

e. Siapkan baskom (baskom B) dengan dimeter yang sama di luar timbangan

f. Angkat dan letakkan baskom A dan saringan ke atas timbangan

g. Tarakan timbangan ke $0.0 \mathrm{~g}$, kemudian angkat saringan 
dan pindahkan ke atas baskom $\mathrm{B}$ dengan kemiringan $17-20^{\circ}$

h. Siapkan sampel yang akan dicek Drained Weightnya, buka tutup kaleng dengan pembuka kaleng, hati-hati supaya tidak ada yang tumpah

i. Kemudian tuangkan sampel dari kaleng kedalam saringan di atas baskom B untuk meniriskan airnya setelah dituang, nyalakan atau start timer untuk menghitung waktu 2 menit sampai habis

j. Setelah alarm timer berbunyi atau setelah 2 menit, angkat saringan berisi nanas dari baskom B dan letakkan diatas baskom A dalam timbangan

k. Catat hasil sebagai drained weight yaitu 1700 geram.

\section{Penentuan Jumlah (count)}

Prinsip kerja adalah 100 gram sampel dihitung untuk mengetahui berat perpotongan dan kemudian angkat "berat per potongan" dikonversikan ke drained weigth sampel PSP untuk mengetahui jumlah dalam satu kaleng.

Tujuan : Untuk mengetahui berapa jumlah dalam satu potongan.

Peralatan/Bahan :
1. Sampel PSP
2. Baki
3. Sendok
4. Timbangan

Cara kerja :

1. Identitas sampel dan hasil pengecekan $\mathrm{T} 8 \mathrm{H}$

2. Perhitungan jumlah (count)

a. Ambil sampel yang telah ditiriskan selama 2 menit (setelah menimbangan drained weigth), timbang kira - kira 100 gram.

b. Hitung jumlah sampel yang beratnya lebih kurang 100 gram

c. Untuk mengetahui berat dalam satu kaleng (berat sampel : banyak potongan nanas)

Contoh :

Diket : $\quad$ Berat sampel $=101,4$

Jumlah potongan $=22$

Dit : Berat perpotongan?

Berat perpotong $=\frac{101,4}{22}$

$$
=4,61
$$

4. Analisis Head Space Sampel PSP (Menentukan ruang hampa)

Tujuan : Untuk mengetahui ruang hampa dari kaleng

Prinsip kerja adalah Sisa ruang hampa dalam kaleng yang tidak terisi oleh syrup merupakan ruang hampa.

Peralatan/Bahan :

1. Sampel nanas kaleng

2. Pocket Depth Head Space (penggaris head space)

Cara Kerja :

1. Siapkan sampel nanas kaleng

2. Siapkan alat penggaris Head Space (penggaris head space)

3. Buka tutup kaleng sampel dan isinya tidak boleh keluar sebelum head space diukur

4. Ambil penggaris head space dan standarisasikan penggaris sampai menunjuk angka 0 sebelum digunakan 
5. Lakukan pengecekan head space pada 3 titik disekeliling bibir kaleng

6. Ambil penggaris head space dengan hati-hati dan penggaris tidak boleh bergeser, letakkan pada bibir kaleng dan geser penggarisnya sampai menyentuh cairan dalam kaleng, ruang hampa yang diinginkan yaitu 2,5 $\mathrm{cm}$.

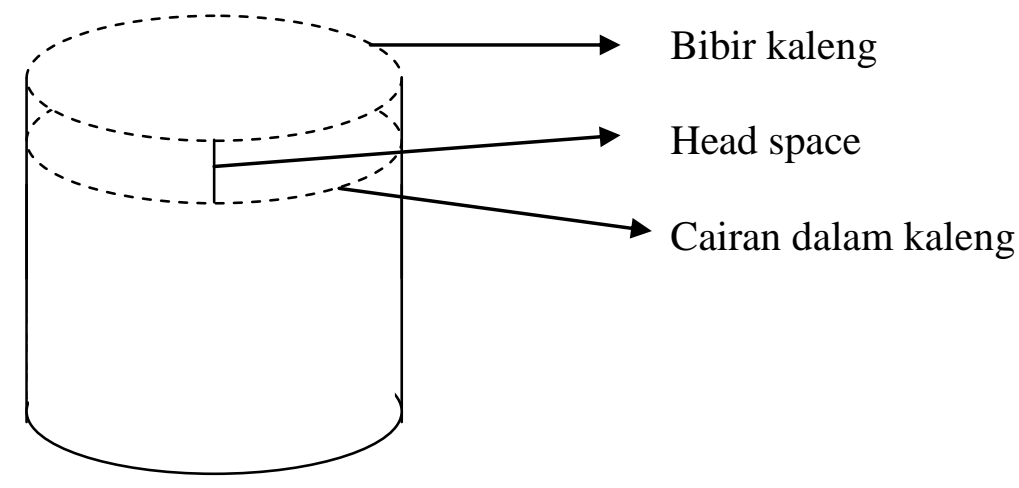

5. Analisa Defect dan Dimensi mekanik selama proses produksi, Potongan Nanas tetapi masih dapat dihitung.

Tujuan : Untuk mengetahui demensi

b. Blemish : Bagian dari potongan nanas yang mempunyai warna atau testur permukaan yang berbeda secara jelas dengan nanas normal, bagian tersebut dikatagorikan blemish jika ukuran lebih dari $2 \mathrm{~mm}$ pada potongan nanas.

Peralatan/Bahan :

1. Sampel nanas kaleng.

2. Baki (wadah untuk sampel)

3. Penggaris

4. Sarung tangan,

c. EVM : Biji, daun, kulit dan bagian-bagian nanas itu sendiri yang bukan merupakan daging atau core buah nanas.

Cara Kerja :

A. Analisis Defect

a. Mashed : Potongan nanas yang telah kehilangan bentuknya yang normal karena perlakuan

B. Uniformity (Keseragaman Bentuk Nanas).

- Thickness (berdasarkan ketebalan)

- Cor (berdasarkan lebar)

- Slaces ( berdasarkan panjang) 


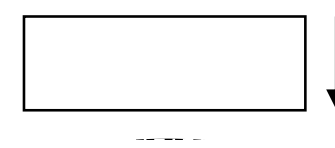

Thickness dengan ukuran $9-10 \mathrm{~mm}$

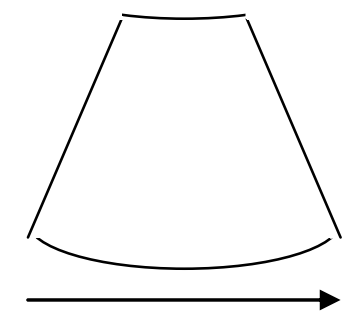

Cor dengan ukuran 29 - $30 \mathrm{~mm}$

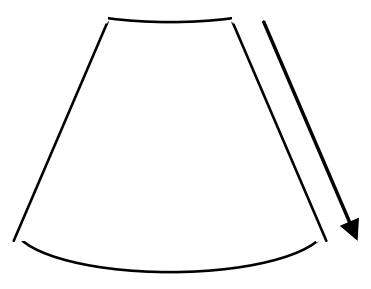

Slaes dengan ukuran $20-21 \mathrm{~mm}$

Gambar 2. Bentuk ukuran potongan nanas

C. Core

a. Core adalah bagian dari nanas yang terletak ditengah nanas (hati nanas).

b. Periksa dan pisahkan semua potongan nanas yang mempunyai core. Pisahkan core dari daging nanas menggunakan dengan decoret (pisau core).

D. Total FOM (Foreign Of Material) adalah benda asing yang bukan merupakan bagian dari nanas.

\section{Pengecekan Organoleptik Sampel Nanas Kaleng}

Tujuan : Untuk mengetahui rasa, aroma, warna, testur di penampakan terhadap produk.

Prinsip Kerja adalah Pengujian kualitas produk dengan parameter uji
Rasa (flafor), Aroma (odor), dan Warna (color), texture dan penampakan terhadap daging buah.

$$
\text { Peralatan dan Bahan }
$$

1. Sampel PSP

2. Air Destilasi

3. Botol semprot (botol air destilasi)

4. Sendok

Cara Kerja :

1. Siapkan Sampel nanas kaleng

2. Pastikan personil yang melakukan pengecekan tidak dalam keadaan sakit yang mengakibatkan kemampuan deteksi berkurang misalkan influenza.

3. Pengecekan Flavour (Rasa)
a. Sebelum
pengecekan pastikan personil yang melakukan pengecekan tidak makan/minum dan merokok selama 2 jam sebelumnya. 
b. Lakukan kumur-kumur menggunakan air aquades

c. Ambil bagian sampel yang berupa cairan $1 / 2$ sendok, masukkan dalam mulut, sebarkan dalam mulut dan telan pelan-pelan sambil rasakan, apakah ada rasa permentasi atau khas nanas.

Pengecekan Aroma (Odor)

a. Sebelum

pengecekan pastikan personil yang melakukan pengecekan tidak makan/minum dan merokok selama 2 jam sebelumnya.

b. Ambil sampel dalam sendok dengan menggunakan sebelah tangan, lalu cium sampel tersebut dengan melewatkannya depan hidung, lalu tangan sebelah lagi mengkipas-kipaskan sampel agar baunya keluar dan apakan ada bau permentasi. Bau tidak sedap, dan bau asing yang tidak normal dari bau khas nanas.

Pengecekan Warna (Colour) secara visual

a. Tuangkan seluruh sampel ke dalam baki dan ratakan isinya dengan menggunakan sendok.

b. Periksa keseragaman warna berdasarkan gradenya sesuai dengan persetujuan warna dari buyer, gunakan definisi sebagai berikut :

\footnotetext{
White (muda)

$\left.\begin{array}{l}\text { Pale Yellow (PY) } \\ \text { Light Yellow (LY) }\end{array}\right\}$

- $\quad$ Boleh sebagai material untuk Crush.

Yellow (Y)

Golden Yellow (GY)

Overripe (OVR)

Mixed Color (MXD)

- Untuk produk Choice grade kecuali diperbolehkan oleh buyer atau produk Natural Juice

Untuk produk Light dan Heavy Syrup

- Heavy Syrup

- Boleh sebagai material untuk Juice.

- Campuran warna sampai tiga tingkat boleh untuk Fizza dan Pieces saja
}

Pengecekan Texture (texture atau susunan jaringan material nanas)

a. Firm atau Porous yang dinamakan "Firm" jika jaringan material nanas kompak dan agak keras (tidak lunak), dan sebaliknya jika material nanas tidak kompak (biasanya berongga-rongga) dan jika ditekan mudah patah maka material nanas tersebut "Porous". b. Juicy atau Not Juicy artinya adalah Juicy adalah jika material nanas berair atau mengandung banyak air, untuk mengetahui dapat ditekan dengan jari tangan dan lihat apakah berair banyak atau tidak. Jika tidak berair disebut "Not Juicy". 


\section{Analisa Kimia}

Analisis Brix

Tujuan : Untuk mengetahui tingkat kemanisan syrup agar dapat sesuai dengan yang telah ditentukan

Prinsip : beberapa tetes syrup di letakkan diatas prisma refraktometer, kemudian baca skala dalam derajat brix

$$
\begin{array}{ll}
\text { Brix } \quad \text { : Water } \\
\\
\text { Juice } \\
\text { Light Syrup } \\
\text { Heavy Syrup }
\end{array}
$$

Peralatan dan Bahan

1. Sampel Juice

2. Sendok atau Spatula

3. Refraktometer

Cara Kerja :

a. Teteskan beberapa cairan sampel ke prisma refraktometer.

b. Tekan tombol "ON" untuk melihat hasilnya angka yang muncul pada display untuk Heavy Syrup $21^{\circ} \mathrm{B}$

\section{Pengecekan pH Sampel Nanas Kaleng}

Tujuan : Untuk mengetahui kadar keasaman pada syrup yang telah ditentukan sesuai dengan spec $\mathrm{pH}: 3,0-$ 4,0

Prinsip kerja adalah Metode pengukuran $\mathrm{pH}$ menggunakan $\mathrm{pH}$ meter prinsipnya terdiri dari gabungan elektroda gelas hydrogen sebagai standar dan elektroda kalomel referns pasangan elektroda ini akan menghasilkan perubahan tegangan $59.1 \mathrm{mv} / \mathrm{pH}$ unit pada suhu $25^{\circ} \mathrm{C}$.

Peralatan dan Bahan :

1. Buffer Solution $\mathrm{pH} 0,4$

2. Buffer Solution pH 0,7

3. Sampel PSP

4. Air destilasi
5. Elektroda $\mathrm{pH}$ Meter

6. $\mathrm{pH}$ Meter

7. Stirer (pengaduk magnetik)

8. Tissue

9. Larutan KCL

10. Beaker

Cara Kerja :

1. Siapkan sampel nanas kaleng

2. Siapkan peralatan $\mathrm{pH}$ Meter (batikg to terkalibrasi secara integnal $33.9^{\circ} \mathrm{B}$ ada stiker "AA, LIBR, "SED")

3. Ambil 21, cgiren dari sampel sebanyak $100 \mathrm{ml}$ pada beaker, aduk sampai homogen dengan menggunakan stirer atau sendok bersih, dan sesuai dengan suhu sampel pada range $20{ }^{\circ} \mathrm{C}-25{ }^{\circ} \mathrm{C}$.

4. Bersihkan elektroda $\mathrm{pH}$ meter dengan air destilasi, kemudian keringkan dengan kertas tissue.

5. Operasikan atau hidupkan $\mathrm{pH}$ meter sesuai dengan cara pengoperasiannya, lakukan kalibrasi harian, setiap akan melakukan pengukuran.

6. Celupkan elektroda tersebut ke dalam cairan sampel, nilah yang dapat dalam $\mathrm{pH}$ meter 3.74

Analisis Acidity (\% keasaman)

Tujuan : Dapat mengetahui derajat keasaman yang digunakan untuk menyatakan tingkat keasaman yang dimiliki oleh suatu larutan.

Prinsip kerja : pada cairan sampel nanas kaleng yang sudah mencukupi masa inkubasi ditambahkan indikator PP, kemudian dititrasi dengan larutan $\mathrm{NaOH}$, setelah semua asam (acid) beraksi dengan $\mathrm{NaOH}$, maka kelebihan $\mathrm{NaOH}$ akan menimbulkan warna pink. 
Peralatan dan Bahan

1. Sampel PSP

2. Pipet $10 \mathrm{ml}$

3. Erlenmeyer $250 \mathrm{ml}$

4. Indikator PP $1 \%$

5. Air destilasi

6. $\mathrm{NaOH}$

7. Biuret

\section{Cara Kerja :}

a. Ambil dengan menggunakan pipet $10 \mathrm{ml}$ sampel, masukkan kedalam Erlemeyer.

b. Tambah $20 \mathrm{ml}$ air destilasi untuk mempermudah melihat perubahan warna yang terjadi. c. Tambah 2-3 tetes indikator PP\% dan guncang beberapa saat.

d. Titrasi sampel dengan larutan $\mathrm{NaOH}$ sampai larutan berubah warna menjadi merah muda (pink).

e. Catat volume yang terpakai.

$\%$ Acidity $=((\mathrm{Vt} \times \mathrm{Nt} \times 0.064) /(\mathrm{Vs}) \mathrm{x}$ $100 \%$

Dimana :

$\mathrm{Vt}=$ Volume titrasi

$\mathrm{Nt}=$ Normalitas $\mathrm{NaOH}$

Vs $=$ Volume sampel

Contoh :

Diket :

$\mathrm{Vt}=5,7$

$\mathrm{Nt}=0,1007$

$\mathrm{Vs}=10 \mathrm{~m}$

$\%$ Acidity $=((\mathrm{Vt} \times \mathrm{Nt} \times 0,064) /(\mathrm{Vs}) \times 100 \%$

$\%$ Acidity $=((5,7 \times 0,1007 \times 0,064) /(10) \times 100 \%$

$=((5,7 \times 0,1007 \times 0,064) /(10) \times 0,01$

$=((5,7 \times 0,1007 \times 0,064) / 0,1$

$=((5,7 \times 0,1007 \times 0,64)$

$=0,367$

$=0,37$

\section{DAFTAR PUSTAKA}

Anonimus. 2010. Analisa Nanas Kaleng pulau Burung

PT. RSUP, 2005. PDK dan Data PT. RSUP Pulau Burung. Indragiri Hilir Riau.
PT. RSUP, 2006. PDK dan Data PT. RSUP Pulau Burung. Indragiri Hilir Riau.

Rukmana, R. 1996. Budidaya Nanas dan Pascapanen. Kanisius. Yogyakarta

Eko Haryanto dan Beny Hendarto, 1996. Perkebunan Nanas. PT. Penebar Swadaya. Jakarta 